\section{NOTES ON STONEHENGE.}

\section{I.-Conditions and Traditions.}

A FTER Mr. Penrose, by his admirable observations $A$ in Greece, had shown that the orientation theory accounted as satisfactorily for the directions in which the chief temples in Greece had been built as I had shown it did for 'those in Egypt, it seemed important to apply the same methods of inquiry with all available accuracy to some example, at all events, of the various stone circles in Britain which have so far escaped destruction. Many attempts had been previously made to secure data, but the instruments and methods employed did not seem to be sufficient.

Much time has, indeed, been lost in the investigation of a great many of these circles, for the reason that in many cases the relations of the monuments to the chief points of the horizon have not been considered; and when they were, the observations were made only with reference to the magnetic north, which is different at different places, and besides is always varying; few indeed have tried to get at the astronomical conditions of the problem.

So far as I know, there has never been a complete inquiry into the stone circles in Britain, but $\mathrm{Mr}$. Lewis, who has paid much attention to these matters, has dealt in a general manner with them (Archaeological Journal, vol. xlix. p. 136), and has further described (Journal Anthropological Institute, n.s., iii.; I900) the observations made by him of stone circles in various parts of Scotland. From an examination of a large number he concludes that they may be divided into different types, each of which has its centre in a different locality. The types are (I) the Western Scottish type, consisting of a rather irregular single ring or sometimes of two concentric rings. (2) The Inverness type, consisting of a more regular ring of better-shaped stones, surrounding a tumulus with a retaining wall, containing a built-up chamber and passage leading to it, or a kist without a passage. (3) The Aberdeen type, consisting of a similar ring with the addition of a so-called " altar-stone" and usually having traces of a tumulus and kist in the middle. In addition to these three types of circles, there are what $\mathrm{Mr}$. Lewis calls sun and star circles, with their alignments of stones, and apparently pro portioned measurements.

It may be useful here to state, with regard to megalithic remains generally, that they may be divided as follows :-

(a) Circles. These may be single or double, and either concentric or not.

(b) Menhirs, or single stones, in some cases still upright, but in many overthrown.

(c) Alignments, i.e. lines of stones in single, double, or in many parallel lines. If these alignments are short they are termed avenues.

(d) Cromlechs; this term generally means a collection of stones; the term is applied to irregular circles in Brittany. It also applies to a single stone raised on the summits of two or more pillar stones forming the end and sides of an irregular vault generally open at one end ("Dolmens of Ireland," Borlase, p. 429).

(e) Coves. A term applied by Dr. Stukeley and others to what they considered shrines formed by three upright stones, thus leaving one side open. I take them to be partially protected observing places. There are well-marked examples at Avebury, Stanton Drew, and Kit's Coity House.

(f) Dolmens, from Dol Men, a table stone. These consist of a flat stone resting on two or more upright stones forming a more or less complete chamber, which may or may not have been sepulchral. I note the following subdivisions, "Dolmen a galérie" having an entrance way of sufficient height, and " Galgal," similar but smaller. In the "Dolmen à l'allée couverte" there is a covered passage way to the centre. It is a more elaborate cove. For the relation between cromlechs and dolmens, see Borlase (loc. cit. and p. 424 et seq.).

With regard to dolmens, I give the following quotation from Mr. Penrose (Nature, vol. 1xiv., September 12, I901) :-

"Near Locmariaquer in the estuary named Rivière d'Auray, there is an island named Gavr' Inis, or Goat Island, which contains a good specimen of the kind of dolmen which has been named ' Galgal.'

"At the entrance our attention is at once arrested by the profusion of tracery which covers the walls. From the entrance to the wall facing us the distance is between $5^{\circ}$ and 60 feet. The square chamber to which the gallery leads is composed of two huge slabs, the sides of the room and gallery being composed of upright stones, about a dozen on each side. The mystic lines and hieroglyphics similar to those above mentioned appear to have a decorative character.

"An interesting feature of Gavr' Inis is its remarkable resemblance to the New Grange tumulus at Meath. In construction there is again a strong resemblance to Mæs-Howe, in the island of Orkney. There is also some resemblance in smaller details."

While we generally have circles in Britain without, or with small, alignments, in Brittany we have alignments without circles, some of them being on an enormous scale ${ }^{1}$; thus at Menec (the place of stones) we have eleven lines of menhirs, terminating towards the west in a cromlech, and notwithstanding that great numbers have been converted to other uses, I 169 menhirs still remain, some reaching as much as 18 feet in height.

The alignments of Kermario (the place of the dead) contain 989 menhirs in ten lines. That of Kerlescant (the place of burning), which beginning with eleven rows is afterwards increased to thirteen, contains altogether 579 stones and thirty-nine in its cromlech, with some additional stones.

Both circles and alignments are associated with holidays and the lighting of fires on certain days of the year. This custom has remained more general in Brittany than in Britain.

At Mount St. Michael, near Carnac, the custom still prevails of lighting a large bonfire on its summit at the time of the summer solstice; others kindled on prominent eminences for a distance of twenty or thirty miles round reply to it. These fires are locally called "Tan Heol," and also by a later use, Tan St. Jean.

In Scotland there was a similar custom in the first week in May under the name of Bel Tan, or Baal's Fire; the synonym for summer used by Sir Walter Scott in the "Lady of the Lake":-

Ours is no sapling chance-sown by the fountain

Blooming at Beltane in winter to fade.

At Kerlescant the winter solstice is celebrated by a holiday, whilst Menec greets the summer solstice, and Kermario the equinoxes, with festivals. The adoration paid these stones yielded very slowly to Christianity. In the church history of Brittany the Cultus Lapidum was denounced in $65^{8}$ A.D.

Many of the fallen menhirs in these alignments have been restored to their upright position by the French Government. Some of them may have been overturned in compliance with the decree of $65^{8} \mathrm{~A}$.D. above referred to. Several of the loftier menhirs are surmounted by crosses of stone or iron.

1 "' The French Stonehenge : an Account of the Principal Megalithic Remains in the Morbiban Archipelago." By T. Cato Worsfold, F.R.Hist.S. F.R.S.L. (London: Bemrose and Sons, Ltd.)

$$
\text { NO. I839, VOL. } 7 \text { I] }
$$


Regarding both circles and alignments in the light of the orientation theory, we may consider simple circles with a central stone as a collection of sightlines from the central stone to one or more of the outer ones, or the interval between them, indicating the place of the rise or setting of either the sun or a star on some particular day of the year, which day will be a new year's day.

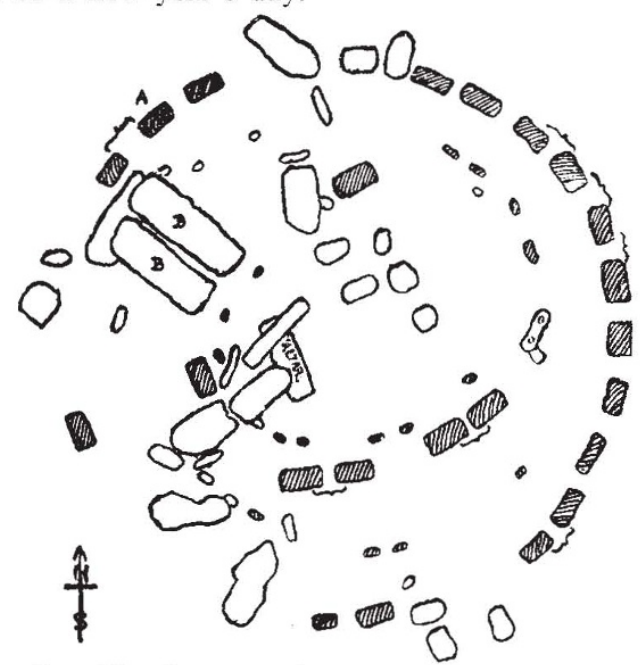

Fig. r.-Plan of Stonehenge, standing stones shaded. A, Stone which fell in $1900 ; \mathrm{BB}$, Stones which fell in 1797 .

Alignments, on the other hand, will play the same part as the sight-lines in the circles.

Sometimes the sight-line may be indicated by a menhir outside, and even at a considerable distance from, the circle.

The dolmens have, I am convinced, been in manv
In order to bring some measurements to test the orientation theory in Britain, I found that Stonehenge is the ancient monument in this country which lends itself to accurate theodolite work better than any other. Avebury and Stanton Drew are known to a great many archæologists; there are also other very wonderful stone circles near Keswick and in other parts of England; but unfortunately it is very much more difficult to get astronomical data from these ancient monuments than it is in the case of Stonehenge, one reason being that Stonehenge itself lies high, and the horizon round it in all directions is pretty nearly the same height, so that the important question of the heights of the hills along the sightline-a matter which is very important from an astronomical point of view, although it has been neglected, so far as I can make out, by many who have made observations on these ancient monuments-is quite a simple one at Stonehenge. Hence it was much easier to determine a date there than by working at any of the other ancient remains to which I have referred.

In orientation generally, such orientation as has been dealt with by Mr. Penrose and myself in Egypt and in Greece, the question frequently was a change in direction in the axis of a temple, or the laying down of the axis of a temple, by means of observations of stars. Unfortunately for us as archæologists, not as astronomers, the changes of position of these stars, owing to certain causes, chiefly the precessional movement, are very considerable; so that if a temple pointed to a star in one year, in two or three hundred years it would no longer point to the same star, but to another one.

Acting on a very old tradition, the people from Salisbury and other surrounding places go to observe the sunrise on the longest day of the year at Stonehenge. We therefore are perfectly justified in assuming that it was a solar temple used for observation in the height of midsummer. But at dawn in mid-

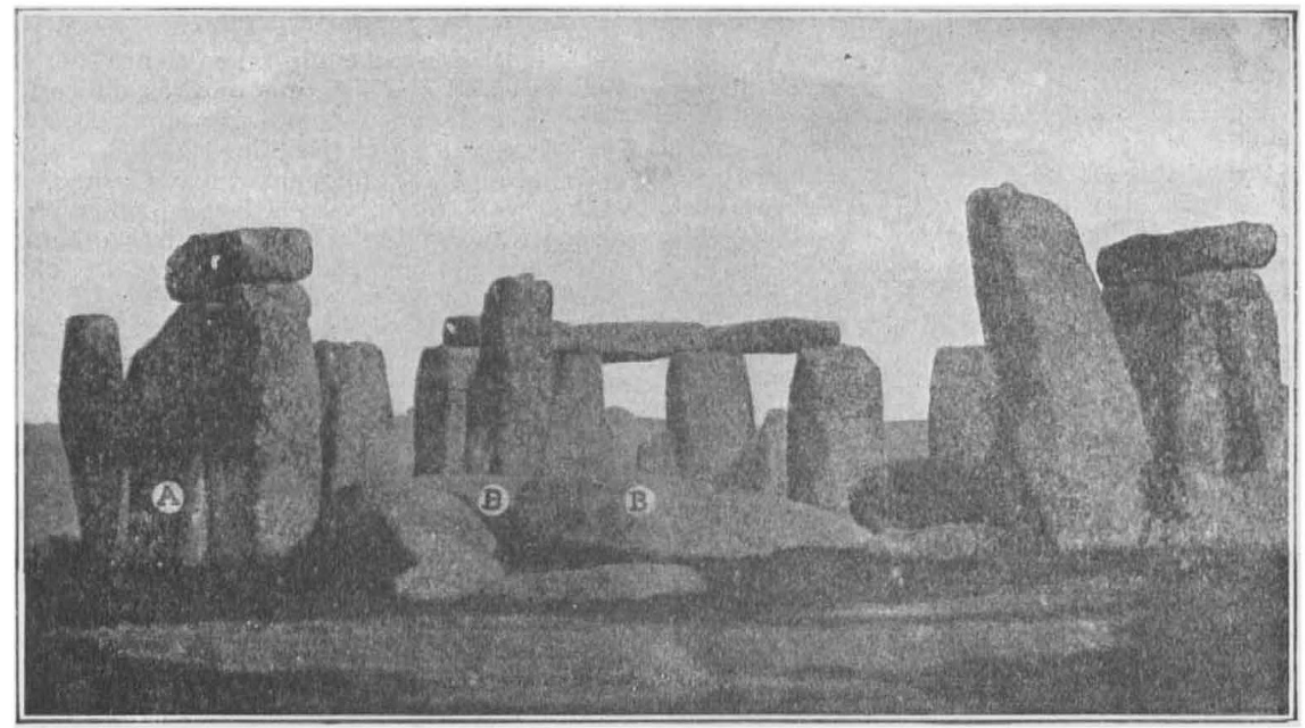

FIG. 2.-View of Stonehenge from the west. A, Stone which fell in 1900 ; Bb, Stones which fell in 1797 (Reproduced from an account of the fallen stones by Mr. Lewis in "Man.")

cases not graves originally, but darkened observing places whence to observe along a sight-line; this would be best done by means of an allée couverte, the predecessor of the darkened naos at Stonehenge, shielded by its covered trilithons.

No. I 839 , vor. 7 [ ] summer in these latitudes the sky is so bright that it is not easy to see stars even if we get up in the morning to look for them; stars, therefore, were not in question, so that some other principle had to be adopted, and that was to point the temple directly to 
the position on the horizon at which the sun rose on that particular day of the year, and no other.

Now, if there were no change in the position of the sun, that, of course, would go on for ever and ever; but, fortunately for archæologists, there is a slight change in the position of the sun, as there is in the case of a star, but for a different reason; the planes of the ecliptic and of the equator undergo a slight change in the angle included between them. So far as we know, that angle has been gradually getting less for many thousands of years, so that, in the case of Stonehenge, if we wish to determine the date, having no stars to help us, the only thing that we can hope to get any information from is the very slow change of this angle; that, therefore, was the special point which Mr. Penrose and I were anxious to study at Stonehenge, for the reason that we seemed in a position to do it there more conveniently than anywhere else in Britain.

But while the astronomical conditions are better at Stonehenge than elsewhere, the ruined state of the monument makes accurate measures very difficult.

Great age and the action of weather are responsible for much havoc, so that very many of the stones are now recumbent, as will be gathered from the accompanying plan, for which I am indebted to Mr. Lewis, who described the condition of the monument in rgor in Man.

But the real destructive agent has been man himself; savages could not have played more havoc with the monument than the English who have visited it at different times for different purposes. It is said the fall of one great stone in I620 was caused by some excavations of the then Duke of Buckingham; the fall of another in I797 was caused by gipsies digging a hole in which to shelter, and boil their kettle; many of the stones have been used for building walls and bridges; masses weighing from $56 \mathrm{lb}$. downwards have been broken off by hammers or cracked off as a result of fires lighted by excursionists.

It appears that the temenos wall or vallum, which is shown complete in Hoare's plan of r810, is now broken down in many places by vehicles indiscriminately driven over it. Indeed, its original importance has now become so obliterated that many do not notice it as part of the structure-that, in fact, it bears the same relation to the interior stone circle as the nave of St. Paul's does to the Lady Chapel.

It is within the knowledge of all interested in archæology that not long ago Sir Edmund Antrobus, the owner of Stonehenge, advised by the famous Wiltshire local society, the Society for the Protection of Ancient Buildings and the Society of Antiquaries, enclosed the monument in order to preserve it from further wanton destruction, and-a first step in the way of restoration-with the skilled assistance of Prof. Gowland and Messrs. Carruthers, Detmar Blow, and Stallybrass, set upright the most important menhir, which threatened to fall or else break off at one of the cracks. This menhir, the so-called "leaning stone," once formed one of the uprights of the trilithon the fall of the other member of which was said to have been caused by the digging and researches of the Duke of Buckingham in 1620 . The latter, broken in two pieces, and the supported lintel, now lie prostrate across the altar stone.

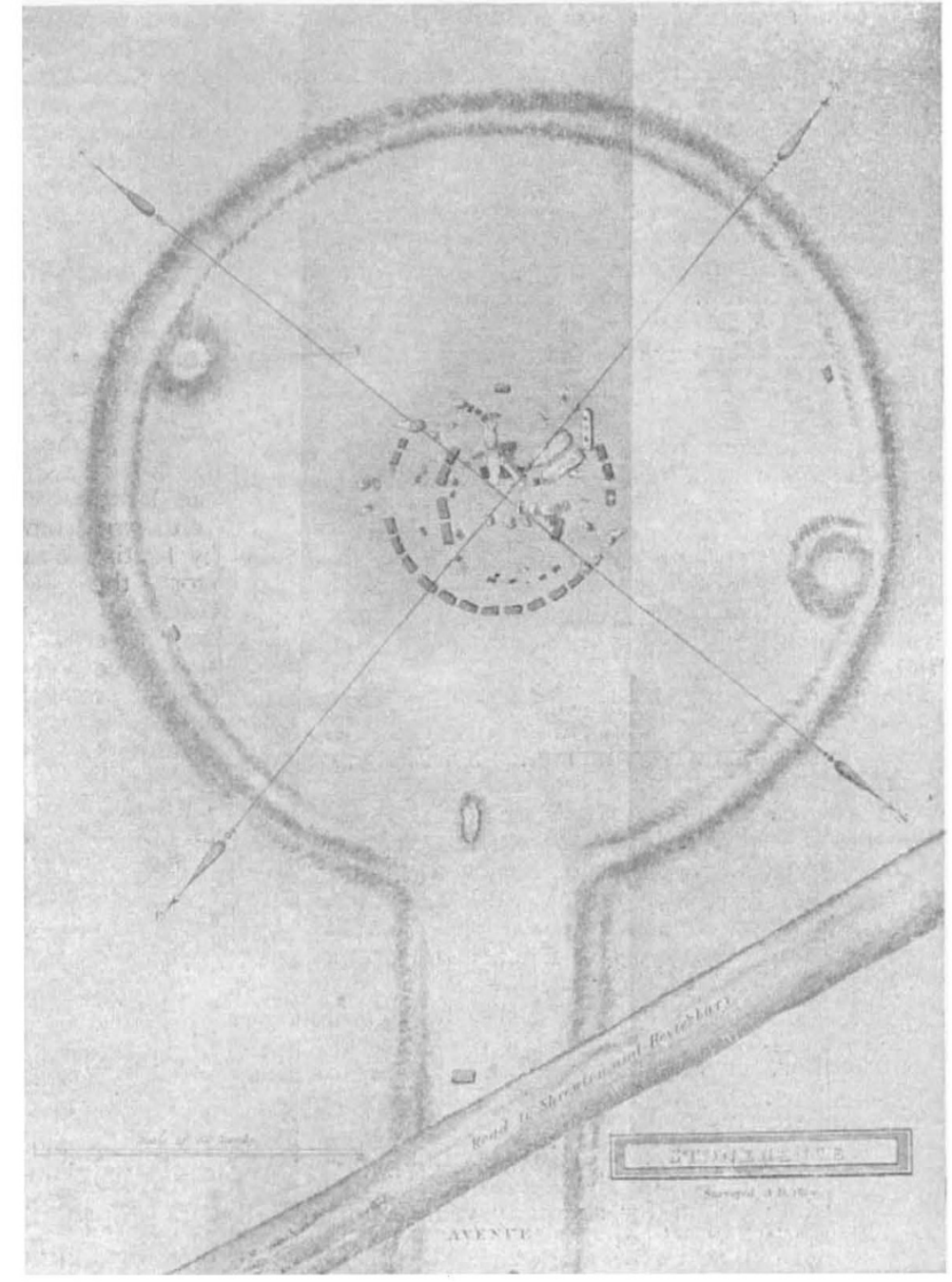

FIG. 3.- - 0 of Hoare's plan of $x 8 \mathrm{ro}$, showing unbroken. Vallum and its relation with the Avenue. No. I 839 , VOL. 7 I ]

This piece of work was carried out with consummate skill and care, and most important conclusions, as we shall see in a subsequent "Note," were derived from the minute inquiry into the conditions revealed in the excavations which were necessary for the proper conduct of the work.

Let us hope that we have heard the last of the work of devastators, and even that, before long, some of the other larger stones, now inclined or prostrate, may be set upright. 
Since Sir Edmund Antrobus, the present owner, has acted on the advice of the societies I have named to enclose the monument, with a view to guard it from destruction and desecration, he has been assailed on all sides. It is not a little surprising that the "unclimbable wire fence "recommended by the societies in question, the Bishop of Bristol being the president of the Wiltshire Society at the time, is by some regarded as a suggestion that the property is not national, the fact being that the nation has not bought the property, and that it has been private property for centuries, and treated in the way we have seen.

Let us hope also that before long the gaps in the vallum may be filled up. These, as I have already stated, take away from the meaning of an important part of one of the most imposing monuments of the world. In the meantime, it is comforting to know that, thanks to what Sir Edmund Antrobus has done, no more stones will be stolen, or broken by sledgehammers; that fires; that excavations such as were apparently the prime cause of the disastrous fall of one of the majestic trilithons in 1797 ; that litter, broken bottles and the like, with which too many British sightseers mark their progress, besides much indecent desecration, are things of the past.

If Stonehenge had been built in Italy, or France or Germany, it would have been in charge of the State long ago.

I now pass from the monument itself to a reference to some of the traditions and historical statements concerning it.

Those who are interested in these matters should thank the Wiltshire Archæological and Natural History Society, which is to be warmly congratulated on its persistent and admirable efforts to do all in its power to enable the whole nation to learn about the venerable monuments of antiquity which it has practically taken under its scientific charge. It has published two most important volumes ${ }^{1}$ dealing specially with Stonehenge, including both its traditions and history.

With regard to Mr. Long's memoir, it may be stated that it includes important extracts from notices of Stonehenge from the time of Henry of Huntingdon (r2th century) to Hoare ( 1812 ), and that all extant information is given touching on the questions by whom the stones were erected, whence they came, and what was the object of the structure.

From Mr. Harrison's more recently published bibliography, no reference to Stonehenge by any ancient author, or any letter to the Times for the last twenty years dealing with any question touching the monuments, seems to be omitted.

It is very sad to read, both in Mr. Long's volume and the bibliography, of the devastation which has been allowed to go on for so many years and of the various forms it has taken.

As almost the whole of the notes which follow deal with the assumption of Stonehenge having been a solar temple, a short reference to the earliest statements concerning this view is desirable; and, again, as the approximate date arrived at by $\mathrm{Mr}$. Penrose and myself in 1901 is an early one, a few words may be added indicating the presence in Britain at that time of a race of men capable of designing and executing such work. I quote from the paper com-

1 "The Wiltshire Archæological and Natural History Magazine. Stone-
benge and its Barrows." By William Long, M.A., F.S.A (1876.)
"Ihe Wiltshire Archæological and Natural History Magazine. Stone-
henge Biblingraphy Number." By W. Jerome Harrison. (I9oz.) No 1839 , vol. 7 I] municated by Dr. Penrose and myself to the Royal Society :-

"As to the first point, Diodorus Siculus (ii., 47) has preserved a statement of Hecatæus in which Stonehenge alone can by any probability be referred to.

"We think that no one will consider it foreign to our subject to say a word respecting the Hyperboreans.

"Amongst the writers who have coiupied themselves with the mythology of the ancients, Hecatæus and some others tell us that opposite the land of the

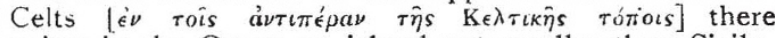
exists in the Ocean an island not smaller than Sicily, and which, situated under the constellation of The Bear, is inhabited by the Hyperboreans; so called because they live beyond the point from which the North wind blows. . . . If one may believe the same mythology, Latona was born in this island, and for that reason the inhabitants honour Apollo more than any other deity. A sacred enclosure $[\nu \hat{\eta} \sigma o \nu]$ is dedicated to him in the island, as well as a magnificent circular temple adorned with many rich offerings. . . The Hyperboreans are in general very friendly to the Greeks.

"The Hecatæus above referred to was probably Hecatæus of Abdera, in Thrace, fourth century B.c.; a friend of Alexander the Great. This Hecatæus is said to have written a history of the Hyperboreans: that it was Hecatæus of Miletus, an historian of the sixth century B.c., is less likely.

"As to the second point, although we cannot go so far back in evidence of the power and civilisation of the Britons, there is an argument of some value to be drawn from the fine character of the coinage issued by British kings early in the second century B.C., and from the statement of Julius Cæsar ("De Bello Gallico,' vi., c. 13) that in the schools of the Druids the subjects taught included the movements of the stars, the size of the earth and the nature of things (Multa præterea de sideribus et eorum motu, de mundi magnitudine, de rerum natura, de deorum immortalium vi ac potestate disputant et juventuti tradunt).

"Studies of such a character seem quite consistent with, and to demand, a long antecedent period of civilisation."

Henry of Huntingdon is the first English writer to refer to Stonehenge, which he calls Stanenges. Geoffrey of Monmouth $\left(x_{1} 3^{8}\right)$ and Giraldus Cambrensis come next.

In spite of Inigo Jones's (1600) dictum that Stonehenge was of Roman origin, Stukeley came to the conclusion in 1723 that the Druids were responsible for its building, and Halley, who visited it in I720probably with Stukeley-concluded from the weathering of the stones that it was at least 3000 ycars old; if he only had taken his theodolite with him, how much his interest in the monument would have been increased!

Davies ("Celtic Researches," I804) endorses Stukeley's view :-

"Amongst the pure descendants of the Celtae, the Druidism of Britain was in its highest repute. The principal seat of the order was found in Mona, an interior recess of that ancient race, which was born in the island. Into that sequestered scene, the Druids, who detested warfare, had gradually retired, after the irruption of the Belgae, and the further encroachment of the Romans. They had retired from their ancient magnificent seat at Abury, and from their circular uncovered temple on Salisbury Plain, in which the Hyperborean sages had once chaunted their hymns to Apollo and Plenyz."

NORMAN LOCKYER. 